Indonesian Journal of Physics and Nuclear Applications

Volume 2, Number 3, October 2017, p. 128-136

e-ISSN 2550-0570, (C) FSM UKSW Publication

\title{
OPTIMIZATION OF COLLIMATOR NEUTRON DESIGN FOR BORON NEUTRON-CAPTURE CANCER THERAPY (BNCT) BASED CYCLOTRON $30 \mathrm{MeV}$
}

\author{
Aniti Payudan ${ }^{1 *}$, Aris Haryadi ${ }^{2}$, Farzand Abdullatif ${ }^{3}$ \\ ${ }^{1}$ Department Physics, FMIPA, Jenderal Soedirman University ${ }^{123}$ \\ J1, Soeparno 61 Karangwangkal, Purwokerto, Indonesia
}

\begin{abstract}
This research in BNCT has a goal to design a collimator that can be used for cancer therapy. Simulations were carried out by MCNPX software. A collimator is designed by cyclotron $30 \mathrm{MeV}$ as a neutron generator. Independent variables varied were material and thickness of each collimator's component to get five of IAEA's standard of the neutron beam. The result is two collimator designs that can pass all IAEA's standard. Those designs are cyclotron collimator I and cyclotron collimator II. Collimator designs obtained are tube collimator consisting of a cylindrical target ${ }^{7} \mathrm{Be}$ length of $1.4 \mathrm{~cm}$ and radius $1 \mathrm{~cm}$, a lead wall with thickness $23 \mathrm{~cm}$, cylindrical heavy water moderator $\left(\mathrm{D}_{2} \mathrm{O}\right)$ with radius $3 \mathrm{~cm}$. Filter Cd-nat for cyclotron collimator I with a thickness of $1 \mathrm{~mm}$ and a radius 3 $\mathrm{cm}$. Cyclotron collimator II uses ${ }^{60} \mathrm{Ni}$ with a thickness of $5 \mathrm{~cm}$ as a filter. The radius aperture is $3 \mathrm{~cm}$. These two collimator designs can be used for cancer treatment with BNCT. Dosimetry calculation and manufacture of prototypes are needed to test the application of this design.
\end{abstract}

Keywords BNCT, radiation safety, boron

\section{INTRODUCTION}

Cancer was the sixth leading cause of death by noncommunicable disease globally in 2014 (World Health Organization, 2014) and is ranked second in 2017 (WHO, 2017). The death rate from this disease was over eight million in $2008(\sim 14 \%$ of the total deaths worldwide) and is predicted to rise to about 12 million ( $\sim 18 \%$ of the total deaths worldwide) by 2030 (Hosmane, Narayan S, Maguire \& Zhu, 2012). International Agency for Research on Cancer revealed that the most common types of cancer are lung cancer (amounting to 1.8 million, constituting $13 \%$ of the total cancer cases), breast cancer (1.7 million, $11.9 \%$ ), and anal cancer (1.4 million, 9.7\%) (IARC, 2013). Glioblastoma multiform is the highest level of deadly brain cancer types (NCI, 2009). As cancer is one of the leading causes of death of the world, effective cancer treatment is needed.

However, despite multidisciplinary therapy approaches including surgery, radiotherapy, different systemic therapies such as antiangiogenic agents, and application of intratumor cavity chemotherapy, long-lasting local tumor control cannot be achieved in most patients with glioblastoma (Rapp et al., 2017). One of the cancer therapies under development is Boron Neutron Capture Therapy (BNCT) (Sardjono, 2014). This is a very promising treatment for brain cancer especially for Glioblastoma Multiform (GBM) (Sauerwein, 2012) because it does not damage healthy cells (Barth et al., 2012). BNCT is a cell- targeting therapy that uses non-radioactive ${ }^{10} \mathrm{~B}$ to capture neutrons with ${ }^{10} \mathrm{~B}(\mathrm{n}, \alpha)^{7} \mathrm{Li}$ reaction (Yasui et al., 2012). The types of neutrons that can be used are a thermal neutron and an epithermal neutron depending on the location of the cancer cells. 
Cancer cells located on the surface are irradiated with thermal neutrons; whereas at a depth greater than $8 \mathrm{~cm}$ they are irradiated with epithermal neutrons (Sauerwein, 2012). For brain cancer therapy, epithermal neutrons with energy ranging from $1 \mathrm{eV}-10 \mathrm{keV}$ are the best choice (Eskandari \& Kashian, 2009). The neutron files used in BNCT are generated by neutron sources.

Neutron source that can be used for the BNCT facility is the cyclotron. Kyoto University Research Reactor Institute (KURRI) and Sumitomo Heavy Industries, Ltd. (SHI) has successfully developed a proton accelerator cyclotron named HM-30. HM-30 produces a proton current of $1.1 \mathrm{~mA}$ with an energy of $30 \mathrm{MeV}$ (Mitsumoto et al., 2010). Cyclotron can produce neutrons with high flux by utilizing ${ }^{7} \mathrm{Li}(\mathrm{p}, \mathrm{n}){ }^{7} \mathrm{Be}$ or ${ }^{9} \mathrm{Be}(\mathrm{p}, \mathrm{n}){ }^{9} \mathrm{~B}$ reactions (Loong et al., 2014) (Kreiner et al., 2016). Beryllium target with a thickness of 1.4 $\mathrm{cm}$ and $1 \mathrm{~cm}$ radius can absorb protons and produce the most optimal neutron flux (Fatimah, 2015). The ${ }^{7} \mathrm{Li}$ target with a length of $2.5 \mathrm{~cm}$ and radius of $1.5 \mathrm{~cm}$ is the best dimension to produce neutrons from the absorption of a $30 \mathrm{MeV}$ proton (Febrianto, 2015). The resulting neutron file must comply with five International Atomic Energy Agency (IAEA) standards to be applicable in BNCT facilities.

A collimator is required to obtain an appropriate epithermal neutron of the IAEA standard. In 2013 the collimator was designed with CNG D-D source. Fast neutron dose and gamma dose component attained IAEA standard, while epithermal neutron flux was still below the IAEA standards i.e. $1.17 \times 10^{6}$ $\mathrm{n} / \mathrm{cm}^{2} \mathrm{~s}$ (Fantidis, Saitioti, Bandekas, \& Vordos, 2013). In 2014, a collimator with
CNG D-D source was designed with the epithermal flux of the collimation of $8.8 \times 10^{6}$ $\mathrm{n} / \mathrm{cm}^{2} \mathrm{~s}$ (Susilowati, 2014). A collimator was also designed from beam port of Kartini reactor (100 $\mathrm{kW}$ ). Neutron epithermal flux passes the IAEA standard of $1.20 \times 10^{9} \mathrm{n} / \mathrm{cm}^{2} \mathrm{~s}$. Materials used were Ni-nat as a wall, 23S as moderator, Cd-nat as neutron thermal filter, and $\mathrm{Pb}$-nat as gamma shield (Wahyuningsih, 2014). The next study also showed that Ni-nat $(95 \%)$ is the optimal material for the reflector coating (F. Erawati et al, 2015). Furthermore, Febrianto (2015) designed a collimator based on ${ }^{7} \mathrm{Li}\left(\mathrm{p} \quad 30 \mathrm{MeV}\right.$, n) ${ }^{7} \mathrm{Be}$ reaction. Three from five standards of IAEA has passed. The existing collimator design does not fully exceed the IAEA standards. Because of this, the collimator required re-designing to attain output that meets IAEA standards.

In this research, a collimator was designed with cyclotron MH 30 source. The simulations were performed using Monte Carlo N-Particle eXtended software (MCNPX). This method was chosen because doing the designing and measuring directly without simulation will cost too much and will also risk a radiation accident. In addition, the Monte Carlo method that is already integrated within the MCNPX can accurately model the neutron transport phenomena (MCNPX Development Team, 2008; (Geng et al., 2014).

\section{EXPERIMENTAL METHOD}

This research was conducted for 6 months (January to June 2016) in the Laboratory of Medical Physics and Computation, Department of Physics, Jenderal Soedirman University, Purwokerto. The necessary tools are a personal computer (PC), Calculator, stationery, MCNPX software, Microsoft Office, notepad ++, surfer, MCNPX vised. 
The method used is simulation using MCNPX software. Collimators work based on the principle of radiation interaction with matter, by shifting or filtering methods. The shifting method uses a moderator to lower the neutron energy. Meanwhile, the filtering method uses materials to absorb neutrons in certain energies (IAEA, 2001). Collimator designing is done by varying the materials and thickness of each part of the collimator. They include walls, moderators, filters, gamma shields and aperture as in Fig 1. All parts were optimized to attain the IAEA standard in Table 1.

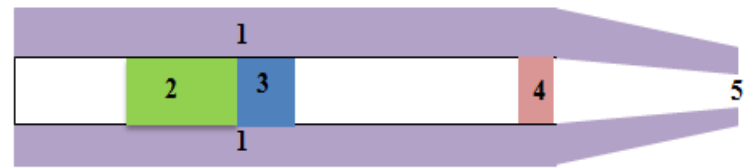

Fig 1. Part of collimator that can attain optimization. With (1) Collimator wall; (2) moderator; (3) filter; (4) gamma shield; (5) aperture.

Table 1. IAEA neutron standard for BNCT

\begin{tabular}{|c|c|c|}
\hline Parameter & $\begin{array}{l}\text { IAEA } \\
\text { Recommendation }\end{array}$ & Tolerance \\
\hline$\Phi_{e}$ & $\geq 1 \times 10^{9} \mathrm{n} / \mathrm{cm}^{2} . \mathrm{s}$ & $\begin{array}{l}\geq 5 \times 10^{8} \\
\mathrm{n} / \mathrm{cm}^{2} . \mathrm{s}\end{array}$ \\
\hline$D_{f} / \Phi_{e}$ & $\begin{array}{l}\leq 2 \times 10^{-13} \mathrm{~Gy} \\
\mathrm{~cm}^{2} / \mathrm{n}\end{array}$ & $\begin{array}{l}\leq 13 \times 10^{-13} \\
\mathrm{~Gy} \mathrm{~cm} / \mathrm{n}\end{array}$ \\
\hline$D_{\gamma} / \Phi_{e}$ & $\begin{array}{l}\leq 2 \times 10^{-13} \text { Gy } \\
\mathrm{cm}^{2} / \mathrm{n}\end{array}$ & $\begin{array}{l}\leq 13 \times 10^{-13} \\
\text { Gy cm} / \mathrm{n}\end{array}$ \\
\hline$\Phi_{t} / \Phi_{e}$ & $\leq 0,05$ & - \\
\hline$J_{\text {tot }} / \Phi_{t o t}$ & $\geq 0,7$ & - \\
\hline
\end{tabular}

Neutrons in BNCT are divided into three parts: thermal neutrons, epithermal neutrons and rapid neutrons. Rapid neutrons are neutrons that have energies greater than 10 $\mathrm{keV}$. Epithermal neutrons are neutrons that have energy in the range between $0.5 \mathrm{eV}$ to 10 $\mathrm{keV}$. The thermal neutrons are neutrons that have energy below $0.5 \mathrm{eV}$ (IAEA, 2001).

\section{RESULTS AND DISCUSSION}

\section{PARTS OF COLLIMATOR}

The collimator is designed by optimizing the material type and the length of each collimator component as shown in Figure 1. The additional component for collimator is the neutronproducing targets. Neutron-producing targets are needed in the cyclotron collimator to convert the proton output of a cyclotron to be a neutron. Two collimator designs were obtained. Detailed explanations of the collimator design results are as follows.

\section{A. Source Modeling}

The cyclotron source is modeled by a point source. The source is defined as a proton particle which is mono directional in the $\mathrm{x}$ direction. The source is modeled with a $30 \mathrm{MeV}$ flux with a $0.7 \times 10^{16}$ proton $/ \mathrm{cm}^{2}$ s flux. The source is still a proton in order to produce the required target material neutrons.

B. Neutron-producing target $\left({ }^{9} \mathrm{Be}\right)$

The materials usually used to produce neutrons are Lithium and Beryllium. In this study beryllium-9 $\left({ }^{9} \mathrm{Be}\right)$ was selected as the target material to produce neutrons from reaction $\mathrm{p}\left({ }^{9} \mathrm{Be}, \mathrm{n}\right){ }^{9} \mathrm{~B}$ was selected because it is relatively more stable when in high-temperature conditions than lithium. ${ }^{9} \mathrm{~B}$ has a melting point of $1287^{\circ} \mathrm{C}$. In this research the target model with a cylinder shape with a thickness of $1.4 \mathrm{~cm}$ and a radius of 1 $\mathrm{cm}$ was used. The model is the result of optimization of $\mathrm{Be}$ as in previous research (Fatimah, 2015). So the thickness of Be was not varied again but was used directly in the configuration. Figure. 2 shows the source of the proton that $\mathrm{Be}$ added as a neutron-producing target material. Model plus $\mathrm{Pb}$ wall is $25 \mathrm{~cm}$ thick. The wall is also a result of previous research optimization (Fatimah, 2015). 

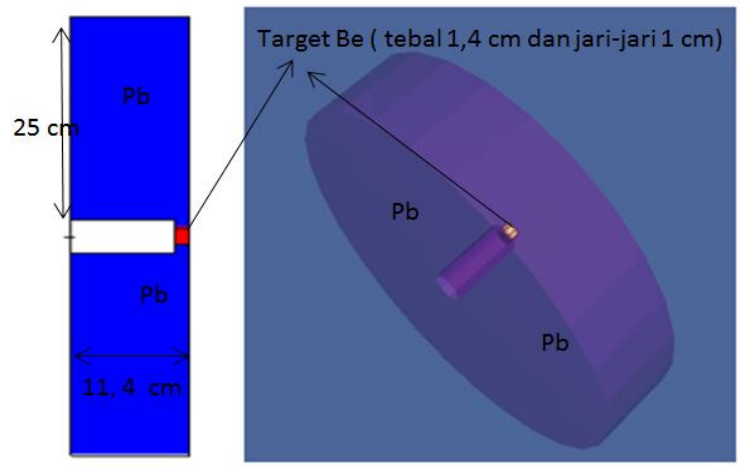

Fig 2. Design ${ }^{9} \mathrm{Be}$ target

The configuration is able to block all protons. All protons reacted with $\mathrm{Be}$ and produced total neutrons with flux of $1.59 \times 10^{12}$ $\mathrm{n} / \mathrm{cm}^{2} \mathrm{~s}$. The amount of thermal neutron flux produced does not exist. The number of epithermal neutron fluxes produced is $7.33 \times 10^{8} \mathrm{n} / \mathrm{cm}^{2} \mathrm{~s}$. Meanwhile, the amount of fast neutron flux produced is $1.75 \times 10^{12}$ $\mathrm{n} / \mathrm{cm}^{2} \mathrm{~s}$. The flux has a spectrum like Figure 3.

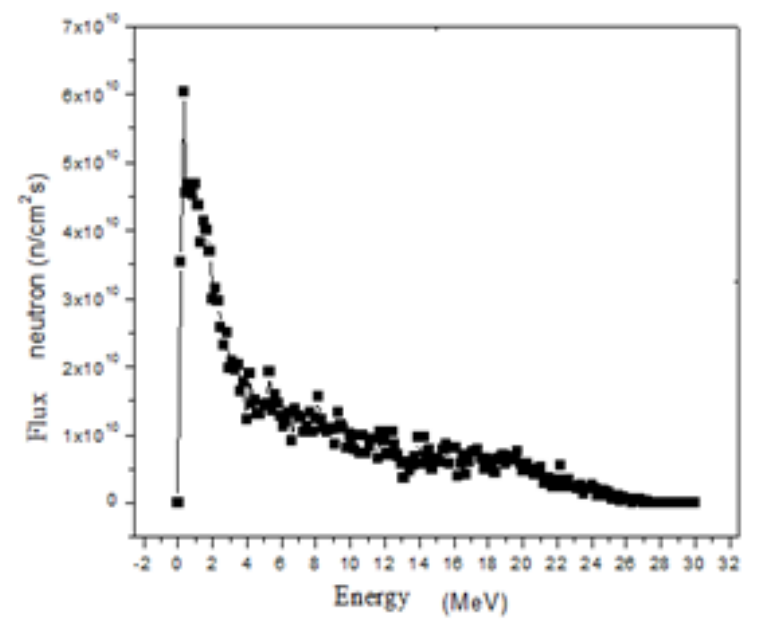

Fig 3. The neutron energy spectrum from p $30 \mathrm{MeV}$

$\left({ }^{9} \mathrm{Be}, \mathrm{n}\right){ }^{9} \mathrm{~B}$ reaction

Based on the spectrum, it is known that the most neutron flux in energy range from 0-2 $\mathrm{MeV}$. Furthermore, in order to obtain the appropriate neutron parameters required by IAEA criteria, a collimator is required.

C. Collimator Wall
The wall used is $25 \mathrm{~cm}$ thick with a density of $11.34 \mathrm{gram} / \mathrm{cm}^{3}$. The lead wall selected refers to previous research, which states that the lead with that dimension is the best configuration to produce the maximum neutron (Fatimah, 2015). Thus, the wall is not optimized for this thickness.

\section{Collimator Wall}

Reducing the energy of a fast neutron to become an epithermal neutron requires a moderator. The moderator chosen to be optimized is $\mathrm{D}_{2} \mathrm{O} . \mathrm{D}_{2} \mathrm{O}$ was chosen because in addition to having a suitable cross-section for moderating properties it is also the best material of moderator test results on CNG D-D collimator design. Variations were made with the addition of a moderator to the source model that targeted $\mathrm{Be}$ and the wall. Moderator $\mathrm{D}_{2} \mathrm{O}$ with cylinder geometry, a constant radius of $3 \mathrm{~cm}$ varied in thickness from 0 to $50 \mathrm{~cm}$ with interval $5 \mathrm{~cm}$ was used. The effect of moderate $\mathrm{D}_{2} \mathrm{O}$ length variation on the number of neutron fluxes is presented in Figure 4. The effect of moderate $\mathrm{D}_{2} \mathrm{O}$ length variations on the fast neutron dose component is presented in Fig 5.

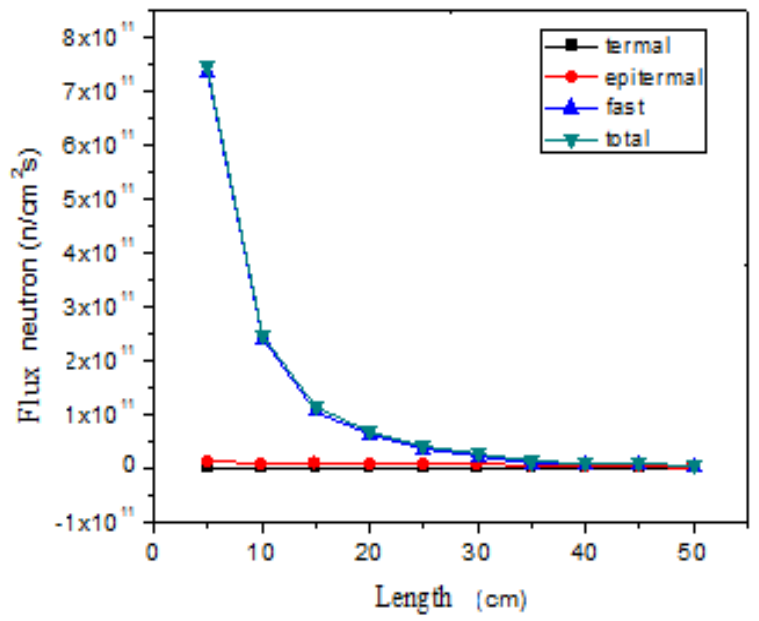

Fig 4. Effect of moderate $\mathrm{D}_{2} \mathrm{O}$ length variation on the number of neutron fluxes 


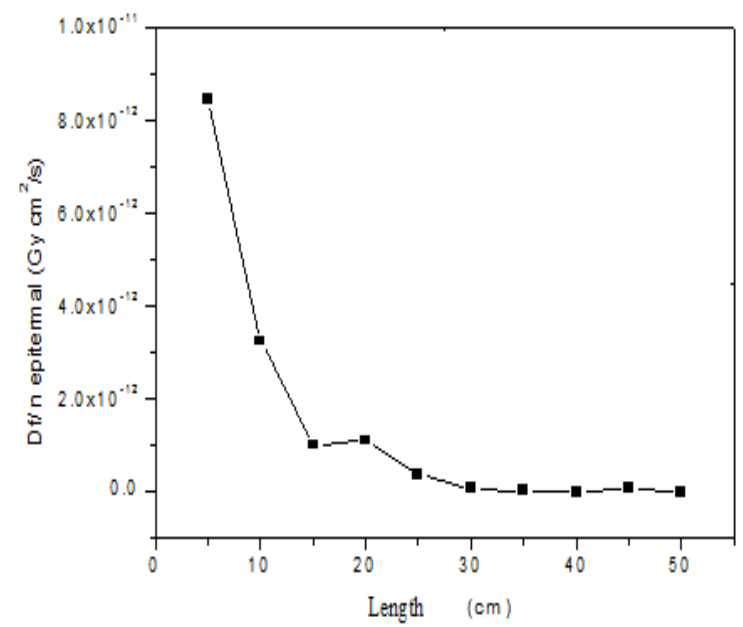

Fig 5. Effect of moderator $\mathrm{D}_{2} \mathrm{O}$ length variation on fast neutron dose component

Based on the graph above it can be concluded that a longer $\mathrm{D}_{2} \mathrm{O}$ moderator will result in a decrease of total neutron flux and rapid neutron flux. This suggests moderation of $\mathrm{D}_{2} \mathrm{O}$ is very effective in lowering rapid neutrons. With a greater moderator length of $\mathrm{D}_{2} \mathrm{O}$, the epithermal flux increases with the increase of thermal neutron flux. This is due to the interaction of neutron inelastic scattering when pounding $\mathrm{H}_{2} \mathrm{O}$. Such interactions lead to changes in the speed of neutrons that pound deuterium or oxygen atoms. The speed of the neutrons after the collision tends to decrease, thereby lowering the neutron energy, which is initially fast neutrons becoming epithermal or thermal. Of all the variations in the length of $\mathrm{D}_{2} \mathrm{O}$ for epithermal neutron flux, the value is above $1 \times 10^{9} \mathrm{n} / \mathrm{cm}^{2} \mathrm{~s}$. So one IAEA standard is definitely fulfilled. Fast neutron dose components tend to fall with increasing moderator length. This is proportional to the rapid decrease in flux neutrons when the moderator is prolonged. At a length of $20 \mathrm{~cm}$, there is a rapid but not significant increase in the dose of neutrons. This is because the rapidly measured neutron dose rate is greater, but there may be no significant physical interactions. The ratio between fast neutron doses with the smallest epithermal neutron flux is at 35 $\mathrm{cm}$ in length. At moderator lengths longer than 35 $\mathrm{cm}$, the rate tends to be constant. The best moderator configuration is a $\mathrm{D}_{2} \mathrm{O}$ cylinder moderator with a length of $35 \mathrm{~cm}$ and a radius of $3 \mathrm{~cm}$. The configuration meets four of the five IAEA criteria including epithermal neutron flux of $3.27 \times 10^{9} \mathrm{n} / \mathrm{cm}^{2} \mathrm{~s}$, the ratio between fast neutron dose with epithermal neutron flux $3.28 \times 10^{14}$ Gy $\mathrm{cm}^{2} / \mathrm{s}$, gamma dose per epithermal flux 0 Gy $\mathrm{cm}^{2} / \mathrm{s}$, and a ratio between current and total flux that has exceeded 0.7 , i.e. 0.718 thermal neutron components. This is due to the nature of the $\mathrm{D}_{2} \mathrm{O}$ moderator that moderates fast neutrons to thermal energy. The longer the moderator is made the higher the thermal neutron components. Table 2 shows the effect of the $\mathrm{D}_{2} \mathrm{O}$ length variation on output neutron compared with IAEA standard. The green color on the chart shows that neutron quality has exceeded IAEA standards. The yellow color implies that neutron quality is at tolerable limits and red color does not meet IAEA standards. To meet all of the requirements, thermal neutrons require thermal filters.

Table 2. Effect of D2O length variation on output neutron compared with IAEA standard

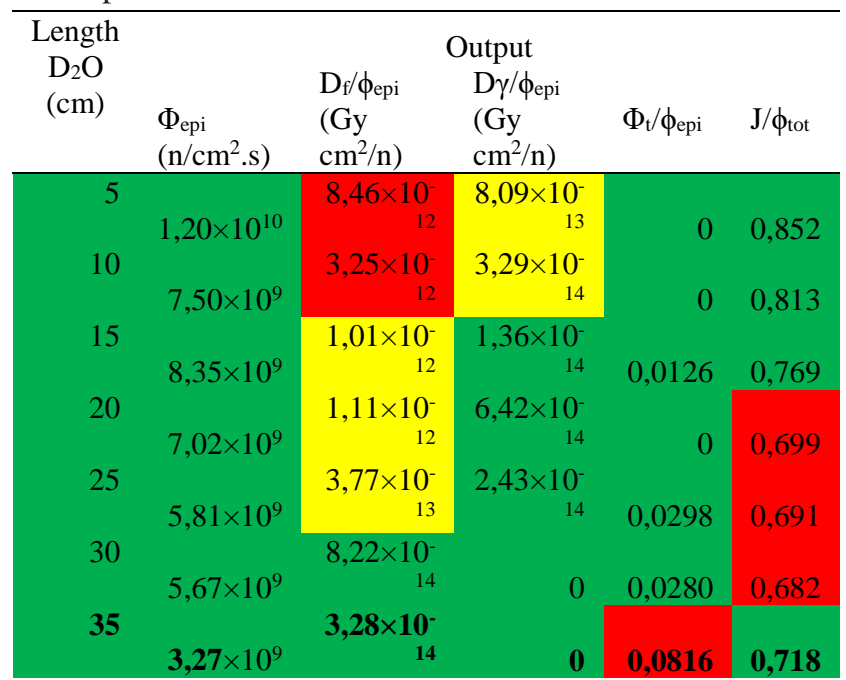




\begin{tabular}{rrrrrr}
40 & & & $1,77 \times 10^{-}$ & \\
45 & $2,14 \times 10^{9}$ & 0 & 13 & 0,04 & 0,582 \\
& & $\begin{array}{r}7,67 \times 10^{-} \\
14\end{array}$ & 0 & 0 & 0,639 \\
50 & $1,91 \times 10^{9}$ & $1,03 \times 10^{-}$ & & & \\
& & $1,05 \times 10^{9}$ & 0 & 0 & 0,544 \\
\hline
\end{tabular}

\section{E. Filter}

In this study, Cd-nat and ${ }^{60} \mathrm{Ni}$ are used. Cdnat with a thickness of $1 \mathrm{~mm}$ is added as a filter, with the consideration of $1 \mathrm{~mm}$ Cd-nat in the cyclotron collimator will be as effective as the optimization in CNG D-D in the previous research (Payudan, A., 2016). The thickness of ${ }^{60} \mathrm{Ni}$ was varied. ${ }^{60} \mathrm{Ni}$ was chosen because at the time of fast filter optimization for the CNN D-D ${ }^{60} \mathrm{Ni}$ collimator it was also effective for reducing thermal neutron flux. Both ${ }^{60} \mathrm{Ni}$ and $\mathrm{Cd}$-nat are modeled as cylindrical filters with radius $3 \mathrm{~cm}$. Table 3 shows the neutron beam quality after the addition of Cd-nat $1 \mathrm{~mm}$. Table 4 shows the effect of variations of the ${ }^{60} \mathrm{Ni}$ length increase on the neutron beam quality.

Table 3. The neutron beam quality after the addition of Cd-nat $1 \mathrm{~mm}$.

\begin{tabular}{|c|c|c|c|c|c|}
\hline $\begin{array}{c}\text { Lengt } \\
\mathrm{h} \\
(\mathrm{cm})\end{array}$ & $\begin{array}{c}\Phi_{\text {epi }} \\
\left(\mathrm{n} / \mathrm{cm}^{2} \mathrm{~s}\right.\end{array}$ & $\begin{array}{c}\mathrm{D}_{\mathrm{f}} / \phi_{\text {epi }} \\
\left(\mathrm{Gy} \cdot \mathrm{cm}^{2} / \mathrm{n}\right.\end{array}$ & $\begin{array}{c}\mathrm{D} \gamma / \phi_{\text {epi }} \\
\left(\mathrm{Gy} \cdot \mathrm{cm}^{2} / \mathrm{n}\right. \\
)\end{array}$ & $\begin{array}{c}\Phi_{\mathrm{t}} / \phi_{\text {ep }} \\
\mathrm{i}\end{array}$ & $\mathrm{J} / \phi_{\text {tot }}$ \\
\hline 0.1 & $\begin{array}{c}3.27 \times 10 \\
9\end{array}$ & $\begin{array}{c}3.28 \times 10^{-} \\
14\end{array}$ & 0 & 0 & 0.70 \\
& & & & 6 \\
\hline
\end{tabular}

Table 4. The effect of variations of the ${ }^{60} \mathrm{Ni}$ length on neutron beam quality.

\begin{tabular}{|r|c|r|r|r|r|}
\hline $\begin{array}{c}\mathrm{L} \\
(\mathrm{cm})\end{array}$ & $\begin{array}{c}\Phi_{\text {epi }} \\
\left(\mathrm{n} / \mathrm{cm}^{2} . \mathrm{s}\right)\end{array}$ & $\begin{array}{c}\mathrm{D}_{\mathrm{f}} / \phi_{\text {epi }} \\
(\mathrm{Gy} \\
\left.\mathrm{cm}^{2} / \mathrm{n}\right)\end{array}$ & $\begin{array}{c}\mathrm{D} \gamma / \phi_{\text {epi }} \\
(\mathrm{Gy} \\
\left.\mathrm{cm}^{2} / \mathrm{n}\right)\end{array}$ & $\Phi_{\mathrm{t}} / \phi_{\text {epi }}$ & $\mathrm{J} / \phi_{\text {tot }}$ \\
\hline 5 & $2.78 \times 10^{9}$ & $\begin{array}{r}1.25 \times 10^{-} \\
13\end{array}$ & $\begin{array}{r}1.36 \times 10^{-} \\
13\end{array}$ & 0 & 0.757 \\
\hline 10 & $2.86 \times 10^{9}$ & $\begin{array}{r}1.11 \times 10^{-} \\
14\end{array}$ & $\begin{array}{r}1.65 \times 10^{-} \\
13\end{array}$ & 0 & 0.685 \\
\hline 15 & $1.44 \times 10^{9}$ & 0 & 0 & 0 & 0.678 \\
\hline
\end{tabular}

Results of optimization of cyclotron collimators
The cyclotron collimator is designed by varying the thickness and material of the collimator component. Two designs were obtained that meet the IAEA criteria. Design I shown in Fig 5 and design II shown in Fig 6.

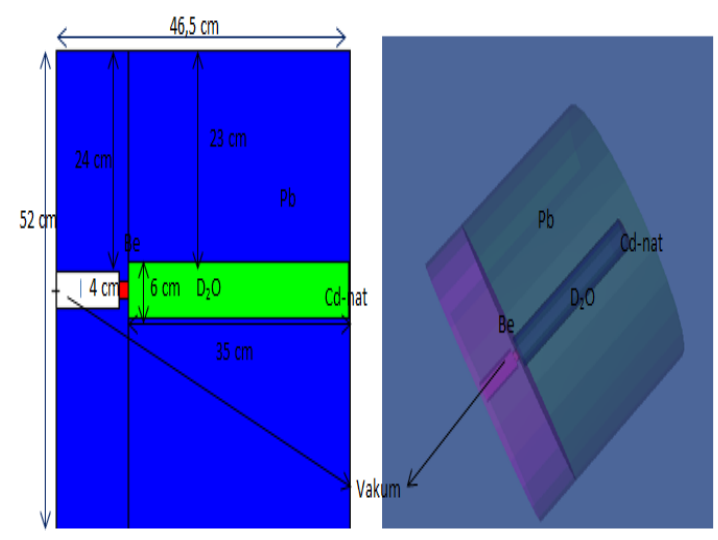

Fig 5. Design collimator cyclotron I

Figure 5 is a tube collimator consisting of a cylindrical ${ }^{9} \mathrm{Be}$ target with a length of $1.4 \mathrm{~cm}$ and a radius of $1 \mathrm{~cm}$. Lead wall $(\mathrm{Pb})$ with a thickness of $23 \mathrm{~cm}$. Moderator of heavy water $\left(\mathrm{D}_{2} \mathrm{O}\right)$ is cylindrical with radius $3 \mathrm{~cm}$. Cd-nat filter for design I with thickness of $1 \mathrm{~mm}$ and radius $3 \mathrm{~cm}$.
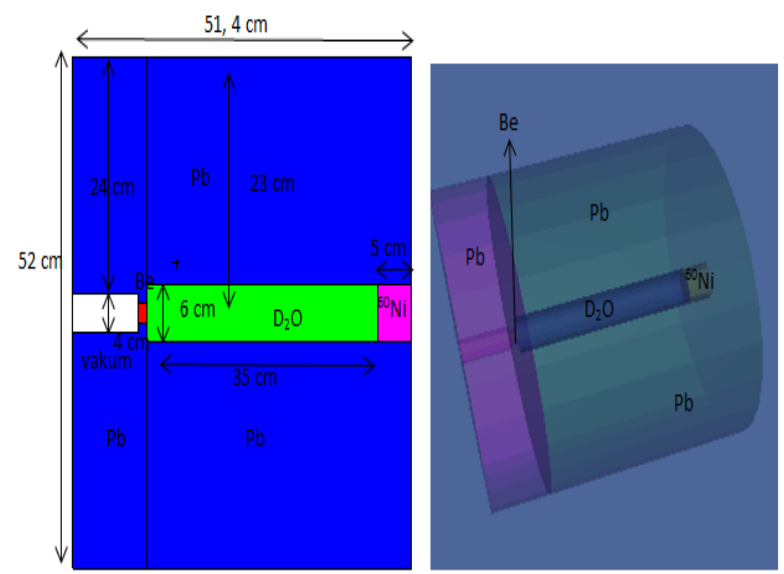

Fig 6. Design collimator cyclotron II

The Collimator cyclotron II consists of a cylinder ${ }^{9} \mathrm{Be}$ target with a length of $1.4 \mathrm{~cm}$ and radius $1 \mathrm{~cm}$. Lead wall $(\mathrm{Pb})$ with a thickness of 
$23 \mathrm{~cm}$. Heavy water moderator $\left(\mathrm{D}_{2} \mathrm{O}\right)$ is cylindrical with a radius of $3 \mathrm{~cm}$ and ${ }^{60} \mathrm{Ni}$ filter with a thickness of $5 \mathrm{~cm}$. The aperture radius is $3 \mathrm{~cm}$. Two of them attained all IAEA standards as in Table 6.

Table 6. Output of collimator cyclotron design

\begin{tabular}{|c|c|c|c|c|c|}
\hline & $\begin{array}{c}\Phi_{\text {epi }} \\
\left(\mathrm{n} / \mathrm{cm}^{2} . \mathrm{s}\right)\end{array}$ & $\begin{array}{c}\mathrm{D}_{\mathrm{f}} / \phi_{\text {epi }} \\
(\mathrm{Gy} \\
\left.\mathrm{cm}^{2} / \mathrm{n}\right)\end{array}$ & $\begin{array}{c}\mathrm{D} \gamma / \phi_{\text {epi }} \\
(\mathrm{Gy} \\
\left.\mathrm{cm}^{2} / \mathrm{n}\right)\end{array}$ & $\begin{array}{c}\Phi_{\mathrm{t}} / \phi \\
\text { epi }\end{array}$ & $\mathrm{J} / \phi_{\text {tot }}$ \\
\hline \multirow[t]{2}{*}{ IAEA } & $\geq 1 \times 10^{9}$ & $\leq 2 \times 10^{-13}$ & $\leq 2 \times 10^{-13}$ & $\begin{array}{l}\leq 0.0 \\
5\end{array}$ & $\geq 0.7$ \\
\hline & $\geq 5 \times 10^{8}$ & $\leq 13 \times 10^{-13}$ & $\leq 13 \times 10^{-13}$ & - & - \\
\hline Design I & $3.27 \times 10^{9}$ & $3.28 \times 10^{-14}$ & $\overline{0}$ & 0 & 0.706 \\
\hline Design II & $2.78 \times 10^{9}$ & $1.25 \times 10^{-13}$ & $1.36 \times 10^{-13}$ & 0 & 0.757 \\
\hline
\end{tabular}

The epithermal neutron flux produced by the design cyclotron collimator I is larger than the design II, but the better collimation rate in in the design II. The neutron spectrum of collimators I and II are shown in Figure 7 and Figure 8.

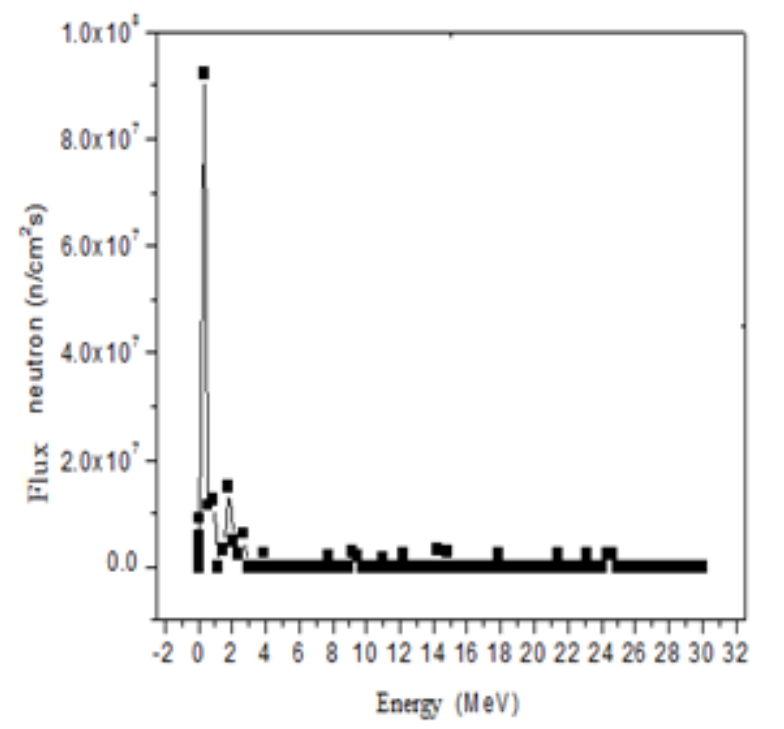

Fig 7. The neutron energy spectrum of cyclotron I

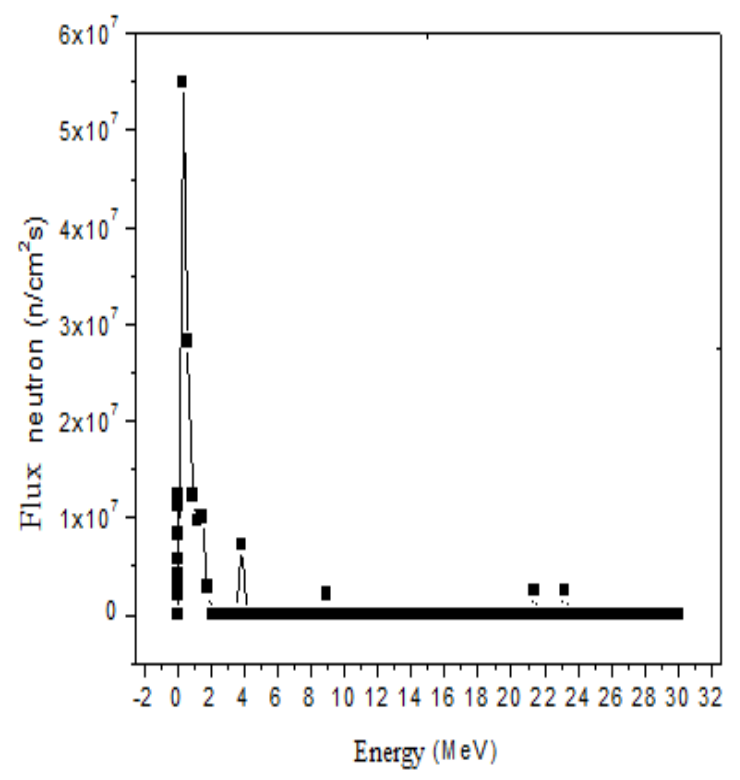

Fig 8. The neutron energy spectrum of cyclotron II

Based on these spectra it is known that collimators produce the most neutrons in low energy ranges. This indicates that the collimation has been successful. The cyclotron collimator designs I and II succeed in moderating the initially high-energy neutrons (fast neutrons) to epithermal neutrons.

\section{CONCLUSION}

Based on the research that has been done, it can be concluded that two designs meet all IAEA's standard. Those designs are cyclotron collimator I and cyclotron collimator II. Collimator designs obtained are tube collimator consisting of a cylindrical target ${ }^{7} \mathrm{Be}$ with a length of $1.4 \mathrm{~cm}$ and a radius of $1 \mathrm{~cm}$, a lead wall with a thickness of $23 \mathrm{~cm}$, and a cylindrical heavy water moderator $\left(\mathrm{D}_{2} \mathrm{O}\right)$ with a radius of $3 \mathrm{~cm}$. Filter $\mathrm{Cd}-$ nat for cyclotron collimator I has a thickness of 1 $\mathrm{mm}$ and a radius of $3 \mathrm{~cm}$. Cyclotron collimator II uses ${ }^{60} \mathrm{Ni}$ with a thickness of $5 \mathrm{~cm}$ as a filter. The radius aperture is $3 \mathrm{~cm}$.

\section{ACNOWLEDGEMENT}


The author says thank you to the Indonesian government that has given the study fund for four years. Thanks to Aris Haryadi and R. Farzand Abdullatif for their guidance, support, motivation, and knowledge so that this research can be resolved. Especially to the parents of the author namely Mr. Eko Wahyudi and Mrs. Siti Khuzaimah who always provide affection, motivation, advice and pray for the success of their daughter. Isdandy Rezki Febrianto is research partner who corrects listing. All those who helped but cannot be mentioned one by one.

\section{RECOMENDATION}

BNCT is a solution to treat cancer in Indonesia. BNCT is very effective because it does not harm healthy cells, being selective and only localized in cancer cells. Methods used such as surgery, chemotherapy, gammablade and Co-60 radiotherapy are less effective because they harm healthy cells. Therefore let us jointly build BNCT for BNCT to be realized immediately. For the Government of Indonesia please apply for permission and support for BNCT development in Indonesia. Let the academics and researchers together research to advance the welfare of the nation especially in the health. For the industry please cooperate to build and realize this BNCT project. For people and cancer sufferers do not worry still try and pray insha Allah all there is way. Keep the spirit! Hopefully BNCT is quickly completed so it can be applied for the treatment cancer in Indonesia.

\section{REFERENCES}

Barth, R. F., H Vicente, M. G., Harling, O. K., Kiger, W., Riley, K. J., Binns, P. J., ... Kawabata, S. (2012). Current status of boron neutron capture therapy of high grade gliomas and recurrent head and neck cancer. Radiation Oncology, 7 (1), 146. https://doi.org/10.1186/1748-717X-7-146

Eskandari, M. R., \& Kashian, S. (2009). Design of moderator and multiplier systems for D-T neutron source in BNCT. Annals of Nuclear Energy, $\quad 36 \quad$ (8), 1100-1102. https://doi.org/10.1016/j.anucene.2009.05.0 05

Fantidis, J. G., Saitioti, E., Bandekas, D. V, \& Vordos, N. (2013). Optimised BNCT facility based on a compact D-D neutron generator, 11 (4).

Fatimah, N., (2015). Optimasi dimensi Target Berillium dan Dinding Target Timbal dalam Menghasilkan Fluks Neutron Menggunakan Simulasi Program MCNPX. Undergraduate Thesis. Purwokerto: Universitas Jenderal Soedirman.

Febrianto, I.R. (2015). Perancangan Kolimator Neutron untuk BNCT dengan Sumber 7Li ( $p$ $30 \mathrm{MeV}$, n) 7Be Menggunakan Software MCNPX. Undergraduate Thesis. Purwokerto: Universitas Jenderal Soedirman.

F.Erawati, O., Riyatun, and Suharyana. (2015). Modification of Materials and Thickness Layer of Radial Piercing Beamport (RPB) Reflector on Kartini Reactor for Boron Neutron Capture Therapy (BNCT). Indonesian Journal of Applied Physics 5 (1), pp 95-106.

Geng, C., Tang, X., Guan, F., Johns, J., Vasudevan, L., Gong, C., Chen, D. (2014). GEANT4 calculations of neutron dose in radiation protection using a homogeneous phantom and a Chinese hybrid male phantom. Radiation Protection Dosimetry, 168(4), 433-440. https://doi.org/10.1093/rpd/ncv364

Hosmane, Narayan S, Maguire, J. a, \& Zhu, Y. (2012). Boron and Gadolinium Neutron Capture Therapy for Cancer Treatment. Russian Chemical Bulletin, 53(9), 18711888.

IARC, 2013, Latest World Cancer Statistics Global Cancer Burden rises to 14.1 Million 
New Cases in 2012: Marked Increase in Breast Cancers must be addressed. International Agency for Reasearch on cancer.

Kreiner, A. J., Bergueiro, J., Cartelli, D., Baldo, M., Castell, W., Asoia, J. G., ... Tacca, H. (2016). Present status of Accelerator-Based BNCT. Reports of Practical Oncology and Radiotherapy, 21 (2), 95-101. https://doi.org/10.1016/j.rpor.2014.11.00 4

Loong, C. K., Sollychin, R., Wong, R. K., Bradley, K., Piestrup, M. A., \& Liang, T. (2014). The pros and cons of preliminary R\&D of Boron Neutron Capture Therapy based on compact neutron generators: A plan of collaboration. Physics Procedia, $60 \quad$ (C), 264-270. https://doi.org/10.1016/j.phpro.2014.11. 036

MCNPX Development Team., 2008. MCNPX User's Manual. Los Alamos: Los Alamos National Laboratory.

Mitsumoto, T., Fujita, K., Ogasawara, T., Tsutsui, H., Yajima, S., \& Industries, S. H. (2010). BNCT System Using $30 \mathrm{Mev}$ $\mathrm{H}$ - Cyclotron Hm-30 Cyclotron, c, 6-8.

NIH Publication, N. 0.-1558. (2009). What You Need To Know About Brain Tumors. National Cancer Institute, 51. Retrieved from http://www.ncbi.nlm.nih.gov/pubmed/23 050263\%5Cnhttp://www.ncbi.nlm.nih.g ov/pubmed/23026359

Octaviana, E. F., Riyatun, \& Suharyana. (2015). Modification of Materials and Thickness Layer of Radial Piercing Beamport (RPB) Reflector on Kartini Reactor for Boron Neutron Capture Therapy (BNCT). Indonesian Journal of Applied Physics, Vol. 5(1), 95.

Rapp, M., Baernreuther, J., Turowski, B., Steiger, H.-J., Sabel, M., \& Kamp, M. A. (2017). Recurrence pattern analysis of primary glioblastoma. World Neurosurgery, 103, 733-740. https://doi.org/10.1016/j.wneu.2017.04.053 IAEA. (2001). Current Status of neutron capture therapy. IAEA, 2001 (8), (May), 75-77.

Sardjono, Y., 2014. Status Boron Neutron Capture Cancer Therapy di Indonesia. ISBN 987-602-9431-87-2.Yogyakarta: Jogja Bangkit Publisher.

Susilowati, A.D., 2014. Collimator Design for Neutron on Compact Neutron Generator of Boron Neutron Capture Therapy (BNCT) using MCNP 5. Thesis. Yogyakarta: Gadjah Mada University.

Therapy, N. C. (2012). Neutron Capture Therapy. https://doi.org/10.1007/978-3642-31334-9

Wahyuningsih, D., 2014. Optimasi Desain Kolimator untuk Uji In Vivo Boron Neutron Capture Therapy (BNCT) pada Beam Port Tembus Reaktor Kartini Menggunakan Simulasi monte Carlo N Particle 5 (MCNP 5). Thesis. Yogyakarta: Gadjah Mada University

WHO. (2017). World Health Statistics 2017.

World Health Organization. (2014). 103,100. Cancer Country Profiles, 22-23.

Yasui, L., Kroc, T., Gladden, S., Andorf, C., Bux, S., \& Hosmane, N. (2012). Boron neutron capture in prostate cancer cells. Applied Radiation and Isotopes, 70 (1), 6-12. https://doi.org/10.1016/j.apradiso.2011.07.0 01 